\title{
Effect of Dietary Garlic Meal on Histological Structure of Small Intestine in Broiler Chickens
}

\author{
Masoud Adibmoradi ${ }^{1}$, Bahman Navidshad ${ }^{2}$, Jamal Seifdavati ${ }^{2}$ and Maryam Royan ${ }^{3}$ \\ ${ }^{1}$ Department of Basic Sciences, Faculty of Veterinary Medicine, University of Tehran, Tehran 14155-6453, Iran \\ ${ }^{2}$ Department of Animal Science, Faculty of Agriculture, Mohaghegh Ardabili University, Ardabil, Iran \\ ${ }^{3}$ Department of Animal Science, Faculty of Agriculture, Mazandaran University, Sari, Iran
}

\begin{abstract}
This study was conducted to evaluate the effect of garlic (Allium sativum) meal on the intestinal mucosal morphology of broiler chickens between 21 and 42 days of age. A total of 1800, 21 days old Ross 308 broiler chicks were weighed and randomly allotted into $0,0.125,0.25,0.5,1$ and $2 \%$ dietary garlic meal groups of each 100 birds. Experimental diets were formulated by addition of each level of garlic meal to commercial finisher mash diet (CP : 20.45\%, ME : 3,130 kcal/kg), and fed ad libitum for $21 \mathrm{~d}$. At day 42, 15 chicks from each treatment were randomly killed to obtain intestinal samples.

Villus height, epithelial thickness, goblet cell numbers, crypt depth and the ratio of crypt depth to villus height in each intestinal segment were compared using a light microscope. Garlic meal as a feed additive significantly enhanced villus height and crypt depth and decreased epithelial thickness and goblet cell numbers in duodenum, jejunum and ileum of birds. Fundamentally, jejunum and ileum revealed an almost similar morphological alteration to that in the duodenum except that dietary garlic meal supplement resulted in an increase in the ratio of crypt depth to villus height in duodenum but a decrease in jejunum and ileum. In present study, small intestinal morphological changes in chickens due to dietary garlic meal supplement demonstrate that absorptive process could be activated by garlic meal as an antibiotics alternative growth promoter.
\end{abstract}

Key words : broiler chickens, garlic meal, intestinal morphology

J. Poult. Sci., 43 : 378-383, 2006

\section{Introduction}

Antibiotics at subtheraupeutic doses are widely used in animal production to decrease susceptibility to pathogens and disease and to improve meat and egg production. It has been hypothesized that gut microflora decrease nutrient absorption by increasing gastrointestinal tract (GIT) thickness, the rate of digesta passage, and also increased nutrient requirements of the host by increasing turnover of the gut mucous and by competing with the host for a portion of the dietary energy and protein (Ravindran et al., 1984 ; Apajalahti et al., 2004). Solomon and
Tullett (1988) noted taller, narrower, and regularly shaped villi in the ileum of antibiotic treated birds. They concluded that these villi provided greater surface area for absorption.

At the present time, there is increasing pressure to reduce or eliminate the use of antibiotics in poultry feed due to the negative human health issue of antibiotic resistance. On the other hand, the proposed ban of antimicrobial growth promoters in the European union in 2006 and the voluntary reduction in the use of them in other countries have forced producers to look for alternative growth promoters to be used in poultry feed. Non-conventional growth

Received : May 12, 2006, Accepted : July 13, 2006

Correspondence to : Dr. Masoud Adibmoradi, Department of Basic Sciences, Faculty of Veterinary Medicine, University of Tehran, Tehran 14155-6453, Iran

Tel : 00982161117112 Fax : 00982166933222 E-mail : mmadib2000@yahoo.com. 
enhances are utilized in broiler nutrition to improve nutrient digestibility, control of pathogenic microorganisms, facilitate a favorable intestinal microbial balance, and enhancing absorption of calorigenic nutrients across the gut wall through increasing its absorption capacity (Al-Harthi, 2002 ; El-Deek et al., 2003).

Garlic (Allium sativum) is widely distributed and used in all parts of the world as a spice and herbal medicine for the prevention and treatment of a variety of diseases, ranging from infections to heart diseases. Garlic is thought to have various pharmacologic properties. For example, it has been found to lower serum and liver cholesterol (Qureshi et al., 1983), inhibit platelet aggregation (Apitz-Castro et al., 1983), inhibit bacterial growth (Cavallito and Bailey 1944) and reduce oxidative stress (Horie et al., 1992). Tollba and Hassan (2003) found that garlic as a natural feed additive, improved broilers growth, feed conversion ratio (FCR), and decreased mortality rate. Demir et al (2003) indicated that there was a reduction in crypt depth in the ileum of broilers given dietary natural growth promoters such as garlic.

The aim of this work was to evaluate the effect of garlic meal used as growth promoters on morphology of duodenum, jejunum and ileum of broiler chickens during finishing period.

\section{Materials and Methods}

In this experiment one hundred one day old Ross 308 mixed sex broiler chicks were assigned randomly to each of 18 floor pens, creating replicates of 6 experimental treatments. Chickens had ad libitum access to feed during the entire experiment. Birds were managed in accordance with the guidelines of the Ross manual. Tylosin tartrate used prophylactically at 5 to 8 days of age ( $100 \mathrm{~g}$ per 200 liter drinking water) as the sole antibiotic treatment according to usual veterinary recommendation. Diets (Table 1) were formulated to meet all the nutrient requirements of the birds for starter (0 to $21 \mathrm{~d}$ ) and finisher (22 to $42 \mathrm{~d}$ ), phases (National Research Council, 1994). Experiment had a completely randomized design with six treatments and 3 replicates pens of 100 birds each (total of 1800 birds). Treatments were consisted of a common corn-soybean meal based finisher diet supplemented by $0,0.125 \%$, $0.25 \%, 0.5 \%, 1 \%$ or $2 \%$ garlic meal and experiment carried out at 21 to 42 days of age. The ingredients of garlic meal used in experiment were $70 \%$ dried garlic powder and 30\% wheat bran as a carrier.

Table 1. Ingredients and chemical composition of experimental diets

\begin{tabular}{|c|c|c|c|c|c|c|c|}
\hline \multirow[t]{3}{*}{ Ingredients $\%$} & \multirow[t]{3}{*}{ Starter } & \multicolumn{6}{|c|}{ Finisher } \\
\hline & & \multicolumn{6}{|c|}{ - Dietary garlic meal ${ }^{1} \%$} \\
\hline & & 0 & 0.125 & 0.25 & 0.5 & 1 & 2 \\
\hline Corn & 56.24 & 60 & 60 & 60 & 60 & 60 & 60 \\
\hline Soybean Meal & 34.71 & 30 & 30 & 30 & 30 & 30 & 30 \\
\hline Fish Meal & 4 & 3.5 & 3.5 & 3.5 & 3.5 & 3.5 & 3.5 \\
\hline Soybean Oil & 2.13 & 3.25 & 3.25 & 3.25 & 3.25 & 3.25 & 3.25 \\
\hline Dicalcium phosphate & 1.19 & 1.21 & 1.21 & 1.21 & 1.21 & 1.21 & 1.21 \\
\hline Oyster shell & 1 & 1 & 1 & 1 & 1 & 1 & 1 \\
\hline Salt & 0.2 & 0.23 & 0.23 & 0.23 & 0.23 & 0.23 & 0.23 \\
\hline Met & 0.125 & 0.09 & 0.09 & 0.09 & 0.09 & 0.09 & 0.09 \\
\hline Minerals \& vitamins premix & 0.5 & 0.5 & 0.5 & 0.5 & 0.5 & 0.5 & 0.5 \\
\hline \multicolumn{8}{|l|}{ Chemical composition } \\
\hline Apparent metabolizable energy $(\mathrm{kcal} / \mathrm{kg})$ & 2948 & 3130 & 3130 & 3130 & 3130 & 3130 & 3130 \\
\hline Crude Protein & 22.25 & 20.45 & 20.45 & 20.45 & 20.45 & 20.45 & 20.45 \\
\hline Calcium & 0.9 & 0.9 & 0.9 & 0.9 & 0.9 & 0.9 & 0.9 \\
\hline Phosphorous & 0.45 & 0.45 & 0.45 & 0.45 & 0.45 & 0.45 & 0.45 \\
\hline Sodium & 0.15 & 0.15 & 0.15 & 0.15 & 0.15 & 0.15 & 0.15 \\
\hline Metionine & 0.4 & 0.39 & 0.39 & 0.39 & 0.39 & 0.39 & 0.39 \\
\hline Metionine + Cysteine & 0.8 & 0.8 & 0.8 & 0.8 & 0.8 & 0.8 & 0.8 \\
\hline Lysin & 1.28 & 1.2 & 1.2 & 1.2 & 1.2 & 1.2 & 1.2 \\
\hline Ether extract & 4.13 & 6.46 & 6.46 & 6.46 & 6.46 & 6.46 & 6.46 \\
\hline Crude Fiber & 3.71 & 3.4 & 3.4 & 3.4 & 3.4 & 3.4 & 3.4 \\
\hline
\end{tabular}

${ }^{1}$ different levels of garlic meal added to a balanced finisher diet. 
At 42 days of age, 5 mixed sex chicks per replicate pen ( 3 male and 2 female) were randomly sampled for morphometric analysis, and then killed. The intestinal tract was removed immediately and severed from the gizzard and the pancreas was removed. Three 1-centimeter tissue segments were taken from the proximal, middle and distal parts of duodenum, jejunum and ileum sections. All samples from each of those birds were taken from the same area of each section of the tract. Samples stored in 10\% buffered neutral formalin for fixation, where they were gently shaken to remove any adhering intestinal contents. Cross sections ( $5 \mu \mathrm{m}$ thick) of each intestinal segment were processed in low-melt paraffin and stained with hematoxylin and eosin. This procedure causes a longitudinal section of villi. Using a Zeiss light microscope, 15 measurements per intestinal section were made for each parameter and averaged into one value per bird. As a matter of fact, each histological data obtained from the mean of 45 records ( 3 sections and 15 villi per section).

Data on villus height, epithelial thickness, goblet cell number, crypt depth and ratio of crypt depth to villus height, were analyzed with the general linear model procedure and differences among treatments means were classified by Duncan's multiple range test (Version 6.12, SAS Institute, Inc.)

\section{Results}

The most pronounced differences observed between $2 \%$ dietary garlic meal and the control group. Figure 1 illustrates the duodenum villus and crypt condition of these two groups.

The effect of garlic meal on villus height, epithelial thickness, goblet cell number, crypt depth and the ratio of crypt depth to villus height of different sections of the small intestine of experimental birds are shown in Table 2. Villi in the duodenum, jejunum and ileum of birds fed the diets supplemented with increasing levels of garlic meal were found to be correspondingly longer $(\mathrm{P}<0.05)$. Specially, the villus height tended to be higher $(\mathrm{P}<0.05)$ in 1 and $2 \%$ dietary garlic meal groups than that of other groups. Feeding garlic meal significantly decreased epithelial thickness in different sections of the small intestine $(\mathrm{P}<0.05)$ and this reduction was more obvious in 1 and $2 \%$ dietary levels of garlic meal. The goblet cell numbers in the villi of duodenum, jejunum and ileum of birds fed the diets supplemented with more than $0.5 \%$ garlic meal were lower $(\mathrm{P}<0.05)$ than other treatments including control.

In all sections of the small intestine, garlic meal inclusion increased $(P<0.05)$ crypt depth in a dose related manner. The only difference found in the small intestine sections resulting from dietary garlic meal supplement was an increase $(P<0.05)$ in the ratio of crypt depth to villus height in duodenum but a decrease $(P<0.05)$ in jejunum and ileum.

\section{Discussion}

The GIT development and health is the key to productivity in all farm animals and poultry. The digestive functions could be considered the most limiting factors in performances. Overall gut sur-

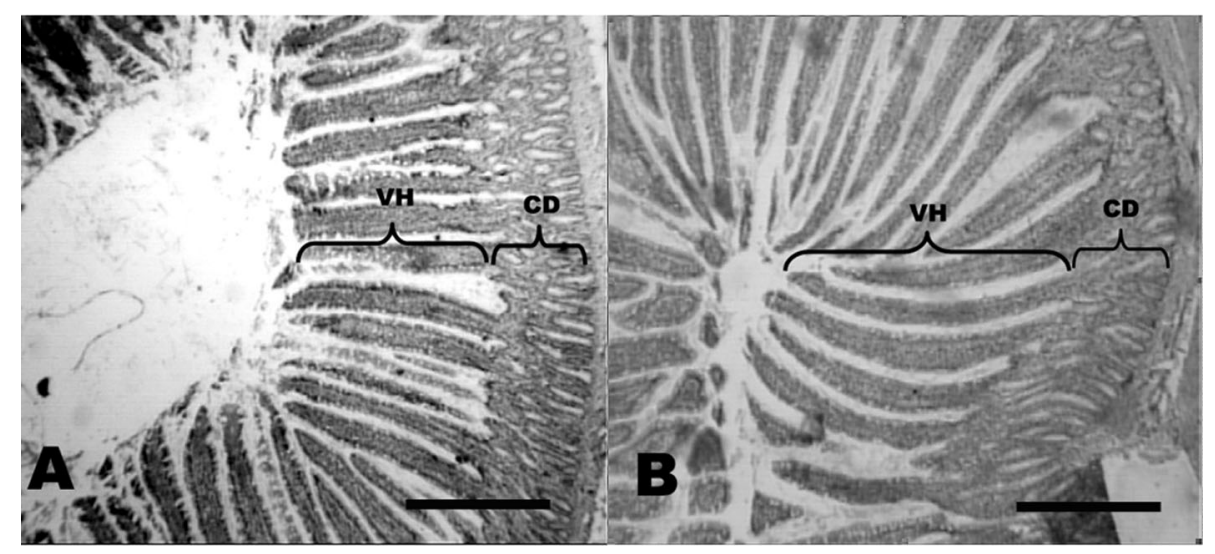

Fig. 1. Sections of a duodenal tissue of broilers chickens. A : Control bird with no dietary garlic meal intake. B : Bird treated group with $2 \%$ dietary garlic meal. In control, the villus structures are short and thickened compared to the birds fed $2 \%$ garlic meal. $\mathrm{CD}=\mathrm{Crypt}$ depth, $\mathrm{VH}=$ Villi height. Hematoxilin and eosin staining. Scale bars represent $500 \mu \mathrm{m}$. 
Table 2. Effects of garlic meal on morphological parameters of small intestine ${ }^{1}$

\begin{tabular}{|c|c|c|c|c|c|}
\hline DGM $\%{ }^{2}$ & $\mathrm{VH}^{3}$ & $\mathrm{ET}^{3}$ & $\mathrm{GN}^{3}$ & $\mathrm{CD}^{3}$ & $\mathrm{C} / \mathrm{V}^{3}$ \\
\hline & \multicolumn{5}{|c|}{ Duodenum } \\
\hline 0 & $1741.1 \mathrm{c}$ & $49.1 \mathrm{a}$ & $10.8 \mathrm{a}$ & $147.1 \mathrm{~d}$ & $0.084 \mathrm{a}$ \\
\hline 0.125 & $1754.9 \mathrm{c}$ & $48.1 \mathrm{ab}$ & $10.2 \mathrm{ab}$ & $147.4 d$ & $0.084 \mathrm{a}$ \\
\hline 0.25 & $1761.2 \mathrm{c}$ & $46.3 b$ & $9.4 \mathrm{bc}$ & $148.6 \mathrm{~cd}$ & $0.084 \mathrm{a}$ \\
\hline 0.5 & $1805.9 b$ & $39.7 \mathrm{c}$ & $9 \mathrm{c}$ & $150.9 \mathrm{c}$ & $0.083 a$ \\
\hline 1 & $2028.6 a$ & $38.3 \mathrm{c}$ & $5.3 \mathrm{~d}$ & $156.6 \mathrm{~b}$ & $0.077 \mathrm{c}$ \\
\hline 2 & $2033.8 \mathrm{a}$ & $35.9 \mathrm{~d}$ & $5.3 \mathrm{~d}$ & $162.7 \mathrm{a}$ & $0.08 \mathrm{~b}$ \\
\hline \multirow[t]{2}{*}{ S.E.M } & 9.9 & 0.67 & 0.38 & 0.93 & 0.0006 \\
\hline & \multicolumn{5}{|c|}{ Jejunum } \\
\hline 0 & $849.6 \mathrm{c}$ & $39.2 \mathrm{a}$ & $10.1 \mathrm{a}$ & $109.2 \mathrm{~d}$ & $0.128 \mathrm{~d}$ \\
\hline 0.125 & $846.8 \mathrm{c}$ & $38.1 \mathrm{ab}$ & $10.9 \mathrm{a}$ & $112.8 \mathrm{c}$ & $0.133 \mathrm{c}$ \\
\hline 0.25 & $849.9 \mathrm{c}$ & $38.4 \mathrm{ab}$ & $10.1 \mathrm{a}$ & $119.6 \mathrm{~b}$ & $0.141 \mathrm{~b}$ \\
\hline 0.5 & $843 c$ & $39.2 \mathrm{a}$ & $9.9 \mathrm{a}$ & $122.1 \mathrm{~b}$ & $0.145 b$ \\
\hline 1 & $881.1 \mathrm{~b}$ & $36.5 b$ & $7.8 \mathrm{~b}$ & $134.2 \mathrm{a}$ & $0.152 \mathrm{a}$ \\
\hline 2 & $908.9 \mathrm{a}$ & $32.2 \mathrm{c}$ & $6.4 \mathrm{c}$ & $135.5 \mathrm{a}$ & $0.149 \mathrm{a}$ \\
\hline \multirow[t]{2}{*}{ S.E.M } & 3.3 & 0.71 & 0.44 & 0.13 & 0.00015 \\
\hline & \multicolumn{5}{|c|}{ Ileum } \\
\hline 0 & $783.2 \mathrm{c}$ & $36.7 \mathrm{a}$ & $11.1 \mathrm{a}$ & $101.7 \mathrm{c}$ & $0.130 \mathrm{~b}$ \\
\hline 0.125 & $797.7 \mathrm{c}$ & $36.5 \mathrm{a}$ & $10.5 \mathrm{a}$ & $104.2 \mathrm{c}$ & $0.131 \mathrm{~b}$ \\
\hline 0.25 & $801.9 \mathrm{c}$ & $34.5 \mathrm{a}$ & $10.1 \mathrm{a}$ & $106.1 \mathrm{c}$ & $0.132 b$ \\
\hline 0.5 & $877.9 \mathrm{~b}$ & $26.7 \mathrm{~b}$ & $8.9 b$ & $118.1 \mathrm{~b}$ & $0.135 \mathrm{~b}$ \\
\hline 1 & $920.5 \mathrm{a}$ & $21 \mathrm{c}$ & $7.6 \mathrm{c}$ & $131.9 \mathrm{a}$ & $0.143 a$ \\
\hline 2 & $924.1 \mathrm{a}$ & $21.3 \mathrm{c}$ & $7.1 \mathrm{c}$ & $132.2 \mathrm{a}$ & $0.143 \mathrm{a}$ \\
\hline S.E.M & 9.2 & 1.15 & 0.4 & 2.07 & 0.003 \\
\hline
\end{tabular}

a-d Values in the same column, with no common superscript differ significantly $(\mathrm{P}<$ 0.05). ${ }^{1}$ Values are means of 45 records from 15 birds from each treatment and their standard errors. ${ }^{2} \mathrm{DGM}=$ Dietary garlic meal percent. ${ }^{3} \mathrm{VH}=$ Villus height $(\mu \mathrm{m})$; ET $=$ Epithelial thickness $(\mu \mathrm{m}) ; \mathrm{GN}=$ Goblet cell number (per $100 \mu \mathrm{m}$ villus height) $; \mathrm{CD}$

$=$ Crypt depth $(\mu \mathrm{m})$; and $\mathrm{C} / \mathrm{V}=$ Ratio of crypt depth to villus height.

face area affect net utilization of dietary nutrients in chicken and will be determined by gross morphological features such as length and cross-sectional area of the duodenal, jejunal and ileal segments, and by finer morphological features such as villus height and surface area of the epithelium in each of those segments (Jin et al., 1998 ; Iji, 1999).

Several researchers have studied intestinal morphology in poultry during the last decade but predominantly from the standpoint of normal development and not with regard to effects of antibiotics and other growth promoters (Uni et al., 1999 ; Geyra et al., 2001). No comprehensive published data are available on the effects of garlic meal on the gut morphology of broiler chickens.

It has been hypothesized that gut microflora decrease nutrient absorption by increasing GIT thickness, the rate of digesta passage, and also increase nutrient requirements of the host by increasing turnover of the gut mucosae and by competing with the host for a portion of the dietary energy and protein (Ravindran et al., 1984 ; Apajalahti et al., 2004).

Krinke and Jamroz (1996) reported reduced duodenal cell proliferation and a thinner epithelial thickness in chicks fed antibiotic, which is in agreement with the observed effect of garlic meal in present research. Thinner intestinal epitheliums enhance nutrient absorption and reduce the metabolic demands of the gastrointestinal system (Visek, 1978).

"Thinning" of the gastrointestinal walls tract may be due to the inhibition of the microbial production of polyamines and volatile fatty acids, known to increase enterocyte turnover rate and activity. This increased net energy committed to maintaining the luminal tissue comes at the expense of more productive purposes such as muscle accretion (Bedford, 2000). The minimization of gastrointestinal bacteria may also ease the competition for vital nutrients between the bird and the microbes (Ferket, 1991).

A shortening of the villi decreases the surface area 
for nutrient absorption. The crypt can be regarded as the villus factory, and a large crypt indicates fast tissue turnover and a high demand for new tissue (Yason et al., 1987). A decrease in either villus height or crypt depth may lead to a reduction in nutrient absorption. The increased crypt depth observed in this study is contrary to the report of Demir et al. (2003) that used female chickens. The villus : crypt ratio is an indicator of the likely digestive capacity of the small intestine. An increase in this ratio corresponds to an increase in digestion and absorption (Montagne, 2003).

Parker and Armstrong (1987) showed that inclusion of an antibiotic in the diet of pigs can result in a elongated villi and a lower crypt : villus ratio, which is indicative of a lower rate of enterocyte-cell migration from the crypt to the villus. The latter conclusion corresponds with the findings of the present study in duodenum section as the inclusion of garlic meal in the diet increased villi height and decreased crypt : villus ratio. The crypt : villus ratio were, however reduced by garlic meal addition in the villi of the jejunum and ileum sections. This is important with respect to axial role of duodenum in absorption. It has suggested that reduced microbial activity in digesta or microbial activity at the level of the brush border would reduce both the damage to enterocytes and the need for cell renewal in the gut (Hughes, 2003).

Goblet cells are responsible for the secretion of mucin that is used for the mucinous lining of the intestinal epithelium (Schneeman, 1982). Thus, a higher density of goblet cells may result in an increase in the secretion of mucin. Intestinal microbes might influence goblet cell dynamics via release of bioactive compounds or indirect activation of the immune system (Bienenstock and Befus, 1980). Dietary garlic meal resulted in a decreased proliferation of goblet cells into the surface of the villus membrane. This is indicative of a decreased host reliance on mucus secretion for protection. In the study of Ferket et al. (2002), contrary to expectations, antibiotic therapy increased goblet cell numbers. Decreasing numbers of viable Gram-positive bacteria, such as Lactobacilli and Bifidobacteria, may increase the presence of Gram-negative species. An increase in these types of microbes may actually necessitate the need for more mucus production and hence more goblet cells (Edens et al., 1997). In present study, garlic meal apparently had a more pronounced effect in this respect.

The results of present study show a dose related differences in gut morphology of birds fed dietary garlic meal which can influence the digestive capacity of the chickens and are indicative of digestive improvement potential of garlic meal as a feed additive.

\section{References}

Al-harthi MA. Efficacy of vegetable diets with antibiotics, and different types of spices or their mixtures on performance, economic efficiency and carcass traits of broilers. Journal of Agricultural Science. Mansoura University, $27:$ 3531-3545. 2002.

Apajalahti J, Kettunen A and Graham H. Characteristics of the gastrointestinal microbial communities, with special reference to the chicken. World's Poultry Science Journal, $60:$ 223-232. 2004.

Apitz-Castro R, Cabrera S, Cruz MR, Ledezma E and Jain MK. Effects of garlic extract and of three pure components isolated from it on human platelet aggregation, arachidonate metabolism, release reaction and platelet ultrastructure. Thrombosis. Research, 32 : 155-169. 1983.

Bedford M. Removal of antibiotic growth promoters from poultry diets : implications and strategies to minimize subsequent problems. World's Poultry Science Journal, $56: 236-243.2000$.

Bienenstock $\mathrm{J}$ and Befus AD. Mucosal Immunology : A Review. Immunology, 41 : 249-270. 1980.

Cavallito C J and Bailey JH. Allicin, the antibacterial principle of Allium sativum. I. Isolation, physical properties and antibacterial action. Journal of American Chemistry Society, 66 : 1950-1951. 1944.

Demir E, Sarica S, Ozcan MA and Suicmez M. The use of natural feed additives as alternatives for an antibiotic growth promoter in broiler diet. British Poultry Science, 44 (Supplement 1) : S44-S45. 2003.

Edens FW, Parkhurst CR, Casas IA and Dobrogosz WJ. Principles of ex ovo competitive exclusion and in ovo administration of Lactobacillus reuteri. Poultry Science, 76 : 179-196. 1997.

El-deek AA, Al-harthi MA, Attia YA and Hannfy MM. Effect of anise (Pimpinella anisum), fennel (Foeniculum vulgare) and ginger (Zingiber officinale Roscoe) on growth performance, carcass criteria and meat quality of broilers. Archive Fur Geflugelkunde, 67 : 92-96. 2003.

Ferket PR. Effect of diet on gut microflora of poultry. Zootechnica, 7/8 : 44-49. 1991.

Ferket PR, Parks, CW and Grimes JL. Benefits of dietary antibiotic and mannanoligosaccharide supplementation for poultry. Multi-State Poultry Meeting, May 14-16. 2002.

Geyra A, Uni Z and Sklan D. Enterocyte dynamics and mucosal development in the posthatch chick. Poultry Science, $80: 776^{-782 .} 2001$. 
Horie T, Awazu S, Itakura Y and Fuwa T. Identified diallyl polysulfides from an aged garlic extract which protects the membranes from lipid peroxidation. Planta Medica, 58 : 468-469. 1992.

Hughes RJ. Energy Metabolism of Chickens Physiological Limitations. A report for the Rural Industries Research and Development Corporation, RIRDC Publication No 02/151. 2003.

Iji PA. The impact of cereal non-starch polysaccharides on intestinal development and function in broiler chickens. World's Poultry Science Journal, 55 : 375-387. 1999.

Jin LZ, Ho YW, Abdullah N and Jalaludin S. Growth performance, intestinal microbial populations, and serum cholesterol of broilers fed diets containing Lactobacillus cultures. Poultry Science, 77 : 1259-1265. 1998.

Krinke AL and Jamroz D. Effects of feed antibiotic avoparcine on organ morphology in broiler chickens. Poultry Science, $75:$ 705-710. 1996.

Montagne L, Pluske JR and Hampson DJ. A review of interactions between dietary fibre and the intestinal mucosa, and their consequences on digestive health in young non-ruminant animals. Animal Feed Science and Technology, 108 : 95-117. 2003.

NRC. Nutrient Requirements of Poultry. (9th rev. ed.). National Research Council. National Academy Press. Washington, D.C., USA. 1994.

Parker DS and Armstrong DG. Antibiotic feed additives and livestock production. Proceedings of the Nutrition Society, 46 : 415-421. 1987.

Qureshi AA, Abuirmeileh N, Din ZZ, Elson CE and Burger WC. Inhibition of cholesterol and fatty acid biosynthesis in liver enzymes and chicken hepatocytes by polar fractions of garlic. Lipids, $18: 343-348.1983$.

Ravindran V, Kornegay ET and Webb KE. Effects of fiber and virginiamycin on nutrient absorption, nutrient retention and rate of passage in growing swine. Journal of Animal Science, 59 : 400-408. 1984.

SAS Institute. SAS ${ }^{\circledR}$ User's Guide : Statistics. Version 6.12 ed., SAS Institute Inc., Cary, NC, USA. 1997.

Schneeman BD. Pancreatic and digestive function. In : Dietary Fibre in Health and Disease (Vahouny GV and Kritchevsky D eds.). pp. 73-83. Plenum Press. New York. 1982.

Solomon SE and Tullett SG. The effect of virginiamycin on the ileum of the domestic fowl. 1. Light and scanning electron microscope observations. Animal Technology, 39 : 157-160. 1988.

Tollba AAH and Hassan MSH. Using some natural additives to improve physiological and productive performance of broiler chicks under high temperature conditions. 2. Black cumin (Nigella Sativa) or garlic (Allium Sativum). Poultry Science, 23 : 327-340. 2003.

Uni Z, Noy Y and Sklan D. Posthatch development of small intestinal function in the poult. Poultry Science, 78 : 215-222. 1999.

Visek WJ. The mode of growth promotion by antibiotics. Journal of Animal Science, 46 : 1447- 1469. 1978.

Yason CV, Summers BA and Schat KA. Pathogenesis of rotovirus infection in various age groups of chickens and turkeys : Pathology. American Journal of Veterinary Research, 48 : 927-938. 1987. 